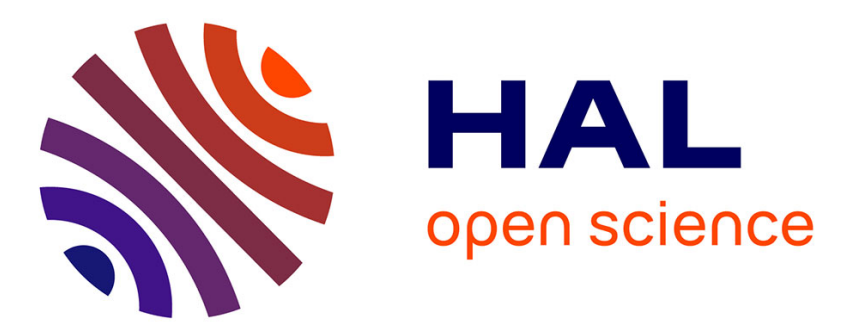

\title{
The New Vitality of Salafism in Côte d'Ivoire: Toward a Radicalization of Ivoirian Islam?
}

\author{
Frédérick Madore
}

\section{To cite this version:}

Frédérick Madore. The New Vitality of Salafism in Côte d'Ivoire: Toward a Radicalization of Ivoirian Islam?. Journal of Religion in Africa, 2016, 46 (4), pp.417-452. 10.1163/15700666-12340090 . halshs01702531

\section{HAL Id: halshs-01702531 \\ https://shs.hal.science/halshs-01702531}

Submitted on 23 Sep 2019

HAL is a multi-disciplinary open access archive for the deposit and dissemination of scientific research documents, whether they are published or not. The documents may come from teaching and research institutions in France or abroad, or from public or private research centers.
L'archive ouverte pluridisciplinaire HAL, est destinée au dépôt et à la diffusion de documents scientifiques de niveau recherche, publiés ou non, émanant des établissements d'enseignement et de recherche français ou étrangers, des laboratoires publics ou privés. 


\title{
The New Vitality of Salafism in Côte d'Ivoire: Toward a Radicalization of Ivoirian Islam?
}

Frédérick MADORE

\begin{abstract}
This article examines recent developments of Salafism in Côte d'Ivoire by exploring how the movement has evolved over the last 25 years through its main national associations and leaders. Although the situation with regard to terrorism has changed in this country since the attack in GrandBassam on 13 March 2016, the intent of this article is to move beyond a reductive focus on security and counterterrorism by painting a more-nuanced portrait of one local manifestation of a global movement often reduced to violence and conflict. Far from becoming radicalized and despite increasing levels of activism, the country's Salafi elites and main national associations have demonstrated civic engagement and opposition to terrorism. They also increased their participation in the socioeconomic arena as well as their willingness to act as a key intermediary between the Muslim community and the country's political leadership.
\end{abstract}

\section{INTRODUCTION}

Compared to other, more strongly Islamic West-African countries such as Senegal, Mali, and Niger, Islam in Côte d'Ivoire has attracted relatively little attention from scholars. However, an increasing number of recent studies have highlighted how the country has nevertheless been affected by global trends and their expressions within sub-Saharan Islam. For example, Miran (2006) describes how a rural Islam that was resistant to change in the decades immediately after independence has given way to an 'urban' and 'modern' Islam, especially in the city of Abidjan. In her various studies LeBlanc $(2000,2003,2009$ a , 2012) underscores the role played by young Muslims in the revitalization of Islam, as well as the increasing influence of religion on Ivorian society. She also highlights the activities of Muslim women in local neighbourhoods, associations, and more generally in the public sphere. LeBlanc $(2007,2009 b, 2014)$ even speaks in terms of the 'feminization of Islamic authority' in Côte d'Ivoire. Savadogo (2005) has studied the vitality of militant Islam in Côte d'Ivoire since the country's transition to multiparty democracy in 1990. From the 1960s to the 1980s, Muslim groups were essentially absent from the political arena. New associations were then created with the establishment of multiparty democracy in 1990 and they began to embrace political activism amid the raging debates on ivoirité that erupted in 1995.

However, despite an increasing number of studies focused on Islam in Côte d'Ivoire, few scholars have looked at the relatively recent rise of Salafism or 'Wahhabism' in this country. Academic interest in this Islamic current in sub-Saharan Africa-still lagging behind the rest of the Muslim world (Boubekeur and Roy 2012; Griffel 2015; Lauzière 2015; Meijer 2013)_has been growing steadily. Several studies have stressed how Salafi movements, widespread throughout the continent, are shaping the religious landscape of many Muslim communities (Cissé 2009; Dumbe 2011; Gilsaa 2015;

Kane 2003; $\quad$ Kobo 2012, 2015; $\quad$ Loimeier 1997; $\quad$ Masquelier 1999; $\quad$ Saint-Lary 2012; Sounaye 2009, 2015). Granted, Miran describes in great depth the Salafi movement's development in Côte d'Ivoire from its origins in the 1940s to 1950s in Bouaké, when a young generation of pilgrims and students, many of whom were Guineans, returned from Mecca and the prestigious Al-Azhar University in Cairo, to the 1990s, tracing its internal evolution through the Association des Musulmans Orthodoxes de Côte d'Ivoire (Association of Orthodox Muslims of Côte d'Ivoire, or AMOCI) as well as the history of its relations with the rest of the country's Muslim community. These relations were often marked by strong tensions and even violent conflicts (Miran 1998, 2006). However, Miran only 
discusses the 1990s in vague terms, and no other studies have paid any significant attention to the development of Salafism in Côte d'Ivoire over the last 25 years. Meanwhile, Salafis, now represented by the Association des Musulmans Sunnites de Côte d'Ivoire (Association of Sunni Muslims of Côte d'Ivoire, or AMSCI), have undergone important changes. The AMSCI has breathed new life into Ivoirian Salafism and given it increasing visibility. They are reaching an increasingly diverse group of Muslims and have collectively become a major player within the national Muslim community.

This article examines recent developments of Salafism in Côte d'Ivoire by exploring how the movement has evolved over the last 25 years through its main national associations and leaders. The violence perpetrated by Boko Haram in Nigeria, Niger, Tchad, and Cameroon, the Al-Shabbaab insurrection in Somalia since 2006, and the 2012 conflict in Mali have had a considerable impact on perceptions of 'Salafism', with the movement often reduced to violence and conflict. In Côte d'Ivoire the situation with regard to terrorism has changed since the attack in Grand-Bassam ${ }^{1}$ on 13 March 2016, when three gunmen opened fire at a beach resort, killing 19 people and injuring many others. The attack, the first of its kind in this country, was claimed by Al Qaeda in the Islamic Maghreb (AQIM), which has also carried out similar attacks on tourist hotspots in $\mathrm{Mali}^{2}$ and Burkina Faso. ${ }^{3}$ The intent of this article is to move beyond a reductive focus on security and counterterrorism by painting a morenuanced portrait of one local manifestation of a global movement. It also seeks to contribute to a better understanding of what Østebø (2005) describes as 'African Salafism'. While being shaped by the distinct national religious, social, and political context, Salafi movements in Côte d'Ivoire are also a product of the dynamic interactions between the local and the global, such as the external connections established by Ivoirian Salafi scholars with the Arab world, especially Saudi Arabia.

It is important to define Salafism and Wahhabism, which are not monolithic categories. The latter term, derived from the name of the eighteenth-century Arab theologian Ibn Abd al-Wahhab, was initially used by French colonial administrators who saw Wahhabism as the main source of inspiration for emerging West-African reformers. The movement's followers have never accepted the label, preferring to sometimes call themselves salafi in reference to the salaf, the pious and glorious predecessors and ancestors of the faith. More often they use the term 'Sunnis', from the Arabic expression Abl as-Sunna or 'community of the people of the Sunnah'. They seek to de-Africanize and purify Islam by rejecting unlawful/illicit innovations $(\text { bida })^{4}$ and popular associationism that combines syncretism, idolatry, and polytheism (shirk, i.e., the deification or worship of anyone or anything other than Allah). They believe these practices have corrupted Islam, and aim to reinstate what it views as the true and authentic Islam. The oneness of God (tawhid) and the completeness of the Islamic tradition as delivered by the Prophet are important principles of the Salafi creed. When describing themselves as Sunnis, some Salafi or Wahhabi Muslims seek to exclude non-Salafi Sunnis, including followers of the Sufi tradition. ${ }^{5}$ In contrast, non-Wahhabi Muslims have come to define themselves in opposition to the label, to which they give a pejorative connotation. They have also been called 'bras croisés' (crossed arms) in opposition to non-Salafi Muslims who pray with their aims unfolded (bras ballant in French). In Côte d'Ivoire Salafis find the label 'Wahhabi' inappropriate. Most chose to call themselves 'orthodox' (orthodoxe) during the 1970s and 1980s when their leaders created the first national Salafi association, Association des Musulmans Orthodoxes de Côte d'Ivoire (AMOCI). They switched to 'Sunnis' (sunnite) in the 1990s, as reflected by the new name of their main national organization in 1997: the Association des Musulmans Sunnites de Côte d'Ivoire (AMSCI). While recognizing the ideological implications of the different labels, this article uses the terms 'Wahhabi', 'Sunni', and 'Salafi' interchangeably.

The article is based on empirical data collected in the course of fieldwork conducted in Abidjan during November 2014 and April 2015, ${ }^{6}$ as well as on research on the national media ${ }^{7}$ and the Islamic presses. ${ }^{8}$ 
The first part of the article discusses the important transition from the AMOCI, which was characterized by serious internal tensions during the 1980s, to the AMSCI, a transition that occurred in the 1990s. The change reflected a desire on the part of the movement's new leaders to start afresh by building bridges with the rest of the Muslim community and by keeping a low profile in debates on ivoirite during the decade. The second part discusses how this Salafi association, which transformed itself into a federation with the creation of new specialized organizations to better reach young people and women, came to rival the main national Muslim associations thanks to the arrival of new leaders, including Fadiga Moussa Al Farouk, and the use of media to spread their message. The final section highlights the political, social, and economic role played by the main Salafi associations since the twenty-first century in Côte d'Ivoire. In addition to organizing various activities and launching repeated appeals for peace during the crisis in the 2000s, these groups also increased their participation in the socioeconomic arena, as they sought to underscore the moderate and legalist nature of their positions, especially with regard to terrorism and radicalization. Furthermore, they show a willingness to act as key intermediaries between the Muslim community and the country's political leadership.

\section{Rediscovering Legitimacy: THE Reorganization OF THE SunNi COMMUNITY IN THE 1990s}

After a long period of lethargy that lasted from 1981 to 1994, which was punctuated by a serious internal crisis inside the AMOCI, Sunni Muslims began to seek greater religious legitimacy for their national association in the 1990s. New leaders sought to regain a degree of visibility on the country's religious scene, as well as credibility in the eyes of political authorities. These aims were reflected in the 1997 decision to change the name of the national organization to AMSCI in the adoption of a moremoderate discourse with regard to other Islamic currents, and in the refusal to participate in the political process and in the debates on ivoirite during the 1990s, in contrast to the country's other Muslim associations.

\section{From AMOCI to AMSCI: Toward a New Beginning for Salafis in Côte d'Ivoire}

During the 1970s the Wahhabi community in Côte d'Ivoire experienced significant growth, leading to the creation of the AMOCI. At a constituent assembly held in Adjamé on 6 July 1975, internal bylaws were adopted and a new national executive council, chaired by El hadj Yao Koum, was chosen. The official decree recognizing the association followed on 28 May 1976 (Fraternité Matin 6 September 1976). However, between 1981 and 1986 this initial period of vitality gave way to a long series of internal crises. According to Miran (2006, 2016), a dispute involving the Bracodi mosque's imam revealed extreme tensions between the local wealthier, educated elite on the one hand, and the enlarging, less-privileged majority-with many non-citizen foreigners, mostly Guineans and, to a lesser extent, Malians_-on the other. The escalation of tensions led to the suspension of the AMOCI and the closure of the Rahma Mosque, ${ }^{9}$ known as Bracodi Bar ${ }^{10}$ to residents of the Adjamé district. Since its construction was completed in 1976 the mosque has served as the association's headquarters and the only Friday mosque for the Sunni population of Abidjan.

Although permission to renew operations was received in 1986, the AMOCI remained inactive for several more years. This long period of inactivity facilitated the creation of several local and regional Wahhabi associations in Côte d'Ivoire, especially in Bouaké, one of the movement's traditional strongholds. Nevertheless, the suspension of the national association, combined with a lack of renewal within the orthodox intelligentsia and the fact that AMOCI was dominated by a largely uneducated and socially disadvantaged base, meant that the movement remained essentially dormant. In the meantime, it lost ground to other Islamic currents that were active in the 1980s and early 1990s (Miran 2006: 293). 
After several years of inactivity, the association gained a new board of directors in December 1994 when Brahima Kanté succeeded El hadj Yao Koum, who had presided over the organization from 1976 to 1993. A few months later the first Wahhabi general meeting since the tensions of 1981-1986 was held in Abidjan on 24 April 1994. Although this was an important moment in the renaissance of the movement, it was really the next regular general meeting, held from 17-19 October 1997, that confirmed the new direction being taken by the national Wahhabi association. By that time Sunnis could count on the leadership of a new generation of intellectuals, including Dr. Moustapha Sy and Dr. Salia Bamba, both of whom held doctorates in Islamic theology. Originally from Samatiguila, Moustapha Sy was the first doctor of Islamic theology to hail from Côte d'Ivoire. He spent 21 years in Saudi Arabia where he earned his doctorate from the Islamic University of Medinah in June 1986. He returned to Côte d'Ivoire in 1988 and settled in Daloa, where he worked to convert new followers and had supported the construction of numerous mosques (Fraternité Matin 7 August 1991). Salia Bamba was the son of Issiaka Bamba, grand imam of the Dioula Mosque in Abidjan. The younger Bamba was himself imam of the Centre d'appel islamique Mosque in Treichville (Abidjan). Born in 1934 in Bondoukou, he began his Quranic studies at the age of six with his grandfather in Dabakala. At 20 he moved back with his father in Abidjan and studied in a madrasa for twelve years. He left for Saudi Arabia in 1964 where he continued his studies and eventually completed a thesis (Islam Info 3-9 January 2007). Both Sy and Bamba supported the development of the AMSCI's links with Saudi Arabia and Kuwait through the personal networks they developed during their studies. ${ }^{11}$

During the 1997 general conference new Sunni intellectuals were able to convince participants of the need to change the association's name. For these emerging leaders the term 'orthodox' created confusion with Orthodox Christians and Orthodox Judaism. As a result, the association was renamed AMSCI, although this decision was not made official until 29 August 2001 (Konaté 2009: 192193). At the same time, the new leaders of the organization sought to regain visibility on the national religious scene of Côte d'Ivoire, as well as legitimacy in the eyes of political and administrative authorities. In particular, these goals involved softening the organization's discourse on other Islamic currents and staying away from political debates.

Quest for Legitimacy in the 1990s: Softening Religious Discourse and Withdrawal from Political Debates

In the 1970s some of the first Salafi organizers_El hadj Yao Koum, Ibrahim Traoré, and Moustapha Doumbia - displayed rigid sectarianism and openly attacked other Muslims in Côte d'Ivoire, whom they described as traditionalists and associationists whose Islamic practices had strayed from orthodoxy. As the movement was restructured during the 1990s, Sunnis moderated their positions with an eye to encouraging greater understanding and tolerance of other Islamic currents as well as to more accommodating attitudes toward Sufism and the Sufi brotherhoods. ${ }^{12}$ By the end of the 1990s it was relatively common to find Salafis worshipping in non-Wahhabi mosques, reflecting a greater spirit of tolerance and cooperation between Wahhabis and non-Wahhabis (Miran 2006).

The new spirit of cooperation was evident in the AMOCI's participation in the creation of the Conseil National Islamique (National Islamic Council, or CNI) on 9 January 1993. This federation was intended to provide the country's various Muslim associations with a united voice. Sunni representatives were also included in the CNI delegation that met with President Félix Houphouët-Boigny on 28 January 1993 to discuss a variety of grievances. These included problems related to the management of the pilgrimage to Mecca, the recognition of Islamic denominational schools, and the creation of a radio station (La Voie 28 January 1993; Fraternité Matin 30-31 January 1993). ${ }^{13}$ In another sign of openness to other Muslims, Dr. Moustapha Sy travelled throughout the country to lead a series of seminars, training sessions, and presentations organized by Islamic associations such as the Association des Élèves et Étudiants Musulmans de Côte d'Ivoire (Association of Muslim Students of Côte d'Ivoire, 
or AEEMCI) ${ }^{14}$ and the Ligue Islamique des Prédicateurs de Côte d'Ivoire (League of Islamic Preachers of Côte d'Ivoire, or LIPCI) ${ }^{15}$ (Fraternité Matin 7 August 1991).

Although the democratic transition that began in 1990 brought new freedoms of association and expression to Côte d'Ivoire, the country's Sunnis did not seize the opportunity to participate in political debates. Rather, they showed a degree of indifference to political questions, or at least abstained from taking public positions on them during the 1990s. As they introduced internal reforms and after a long period of internal conflicts, the leaders of the AMOCI and the AMSCI were more concerned with bringing stability and vitality back to their organization by introducing new and more efficient organizational structures. Their priority was to better reach the faithful, not to debate politics.

During the 1990s there were heated debates on ivoirité and the status of immigrants living in northern Côte d'Ivoire following the succession of President Félix Houphouët-Boigny in December 1993. ${ }^{16}$ However, these questions do not seem to have preoccupied the AMOCI/AMSCI during this decade, in contrast to the new tendency of other Muslim associations' leaders to abandon the spirit of cooperation that had previously defined relations between Muslims and the government. Indeed, representatives of the CNI and the Conseil Supérieur des Imams (High Council of Imams, or COSIM) ${ }^{17}$ condemned interference in their activities by a state bureaucracy that was linked to both the authorities and the Catholic Church. They also spoke out about the poor treatment of Muslims by the government and political authorities (Savadogo 2005). CNI and COSIM's leaders, such as Idriss Koné Koudouss, Aboubacar Fofana, Djiguiba Cissé, and Sékou Sylla, frequently took to the public sphere and the press to condemn the social and economic policies of the Bédié regime (1993-1999) (e.g., Le Jour 9 August 1995, 21-22 October 1996, 16 June 1997, 8 July 1998). In this way these two associations took their place on the national scene as key intermediaries between Muslims and public authorities. In contrast, the AMOCI/AMSCI's leaders remained completely silent and made no public declarations on the issue of ivoirité or the worsening political and social situation in Côte d'Ivoire.

During the highly contentious debates in 2000 on the wording of the constitution of the Second Republic, the AMSCI did not take sides in the constitutional referendum ${ }^{18}$ while Idriss Koudouss, president of the CNI, came out clearly against the proposed text, which in his opinion 'divid[ed] Ivorians rather than bringing them together' (Le Jour 21 July 2000). ${ }^{19}$ At the turn of the twenty-first century the reorganization and revitalization of the Sunni movement was much more focused on youth and women. It would also receive a significant boost from the arrival of a new president in 2007.

\section{Diversity, New Leaders, and Proselytism: The amsci's EfForts to Assert ITSElf IN Côte D'IvoIRE DURING THE FIRST DeCADE OF THE TweNTY-FIRST CENTURY}

At the turn of the twenty-first century the leaders of the AMSCI continued to pursue activities initiated during the previous decade. The revitalization of the movement depended on the will of youth and women to dedicate themselves to da'wa ${ }^{20}$ through the development of the JEMCI and the CFEMSCI. When Fadiga Moussa Al Farouk assumed the leadership of the AMSCI in 2007, it helped establish the association as a player at the national level, capable of rivalling the CNI and the COSIM. The creation of Salafi sister associations, including the Communauté des Élèves et Étudiants Musulmans de Côte d'Ivoire (Community of Muslim Students of Côte d'Ivoire, or CEEMUCI), reflected the growth of a movement that was successfully reaching new audiences. Over the course of the decade the AMSCI sought to further its use of the media to encourage the practice of da'wah, especially through the 2010 launch of its own private radio station, Al Fourquane, in Man. 
The Creation of New Specialized Organizations: Establishing Leadership through Better Support for Youth and Women

During the general conference held in 1997, in addition to changing the name of the association, delegates also recognized the need to reorganize the internal operations of the AMSCI in order to better coordinate the activities of youth and support their mobilization. This desire was reflected in the creation of a specialized organization, the Jeunesse de l'Association des Musulmans Sunnites en Côte d'Ivoire (Youth of the Association of Sunni Muslims of Côte d'Ivoire, or J-AMSCI). ${ }^{21}$ For several years the new youth organization remained largely unknown to the general public and the rest of the Muslim community in Côte d'Ivoire. It was only after a move from $\mathrm{Man}^{22}$ to Abidjan and the organization's second general meeting in August 2008 that it began to be more widely known (Islam Info 10-16 June 2009).

The J-AMSCI progressively gained more autonomy from the AMSCI. Indeed, a few years later in 2002 the AMSCI and its president at the time, Adama Koné, decided at the association's second general conference to reinforce the autonomy of internal organizations that supported youth engagement ( $L e$ Jour 3 June 2002). At the AMSCI's third general conference in August 2007, one of the key recommendations was for the association to be transformed into a federation of Wahhabi associations. By implementing this change the leaders of the AMSCI decided that certain affiliated organizations, including J-AMSCI, would be transformed into associations in their own right. As a result, the J-AMSCI held its first convention in Treichville on 31 May 2009. The movement's popularity was highlighted by the fact that many had to be turned away from the event despite it being held at the Bourse du travail, a 2500-seat venue (Islam Info 10-16 June 2009). In his address Dr. Abdul Karim Dosso, the organization's president since $2008,{ }^{23}$ recalled the work already accomplished by his Salafi movement: 'The purification of the Tawhid and the preservation of the noble tradition of the message of Allah, the modernization of the organization, socio-professional integration, health initiatives, respect from the authorities, and the J-AMSCI's positions on national affairs' (Islam Info 10-16 June 2009). In April 2013 the J-AMSCI finally held a founding conference as an independent association at Al Fourqane Islamic University ${ }^{24}$ in the Yopougon district of Abidjan. The organization's leaders wanted to give it a fresh start. They adopted new by-laws that made official the J-AMSCI's new status as a fully independent association, which was named the Jeunesse Musulmane de Côte d'Ivoire (Muslim Youth of Côte d'Ivoire, or JEMCI) (Islam Info 8-14 May 2013). It is interesting to note that despite the fact that the association maintained its Salafi orientation and its affiliation with the AMSCI, the openness and lack of exclusivity reflected in its new name bore witness to a desire to reach a larger proportion of young Muslims.

At the same time that this organization for youth was being established, the AMSCI created another for women. However, the Cellule Féminine de l'AMSCI (Women's Unit of the AMSCI, or CFAMSCI) proved less dynamic than the J-AMSCI. In the same way as the youth organization, the CFAMSCI was subsequently transformed into an independent association, the Convention des Femmes Musulmanes Sunnites de Côte d'Ivoire (Convention of Sunni Muslim Women of Côte d'Ivoire, or CFEMSCI) at its founding conference in December 2013 at Al Fourqane University (Islam Info 15-21 January 2014). The organization then worked on updating and improving its operations. The constitutions adopted by the JEMCI and the CFEMSCI as independent associations, as opposed to committees or specialized organizations within the AMSCI, highlight the will of the association's older generation to give women and youth a greater degree of autonomy.

After better connecting to the rest of the Ivorian Muslim community in the 1990s, the AMSCI sought to assert its leadership and its conception of Islam during the troubled 2000s. It even began to compete with the country's two main Muslim organizations, the CNI and the COSIM. This was reflected in a 
withdrawal from the CNI in August 2005, despite the fact that the AMSCI had been one of the council's founding members. In September 2005 the AMSCI's imams also withdrew from the COSIM to create their own parallel organization, the Conseil des Imams Sunnites (Council of Sunni Imams, or CODIS). The movement also created the Académie Nationale des Oulémas de Côte d'Ivoire (National Academy of Ulama of Côte d'Ivoire, or ANAOU). This repositioning within the religious landscape progressively bore fruit. Since the AMSCI left the CNI, Sunnis have represented an increasingly important religious force in Côte d'Ivoire's public sphere. This has especially been the case since Fadiga Moussa became president of the AMSCI in 2007, breathing new life into the movement.

\section{The Arrival of Fadiga Moussa Al Farouk.}

Born in 1955, Fadiga Moussa Al Farouk studied Islam with different scholars in Côte d'Ivoire, Burkina Faso, and Ghana until 1972. In 1974, in accordance with his father's wishes and with the help of his older brother, he left for Saudi Arabia, where he continued his studies up to 2003. He earned a licence (undergraduate degree) and a master's degree at the Islamic University of Medinah. He later earned a doctorate from the faculty of Islamic law at Muhammad Boun Saoud University in Riyadh. His thesis passed with honors. Once he completed his studies, he began teaching at the Islamic University of Niger in Say. ${ }^{25}$ During his years overseas as a student he established close links with donor in Saudi Arabia. Fadiga Moussa was chosen to lead the AMSCI in August 2007 at the association's third general conference. His mandate coincided with an intensification of the movement's activities. He was able to bring a new dimension to the association, especially through the construction of mosques and madrasas, and by undertaking development projects. His vast international network established during his studies conferred a great degree of legitimacy and religious authority within the Muslim community of Côte d'Ivoire. ${ }^{26}$

Upon his return to Côte d'Ivoire in 2004, Fadiga Moussa founded Maktab Ta'Awoun ('Cooperation Office'), ${ }^{27}$ an NGO specializing in the construction of mosques, madrasas, and wells in Côte d'Ivoire. Relying on partnerships with other NGOS and support from donors in Saudi Arabia, Maktab Ta'Awoun has been very active. According to Binaté (2016), in recent years, a large part of donations from Arab Muslim countries were destined for Maktab Ta'Awoun. At the same time, the organization has helped expand the influence of the AMSCI from which the NGO is affiliated. Maktab Ta'Awoun claims to have built hundreds of new mosques and madrasas. ${ }^{28}$ For example, in just one of the country's departments-Touba, near Guinea-the AMSCI and Maktab Ta'Awoun built a total of seventeen mosques, Quranic schools, and madrasas (Agence Ivoirienne de Presse 19 January 2015). On top of these achievements, Al Fourqane Islamic University opened in Yopougon district for the 2009-2010 academic year. Fadiga Moussa served as president and rector of the institution. It was a project he had been working on since he had been a master's student. Fadiga Moussa wanted Muslim students in Côte d'Ivoire to be able to pursue their post-secondary studies within the country. He also wanted to create jobs at the university for those who had been educated in Arab countries. Finally, he sought to help train a new generation of scholars specializing in Islamic studies (Islam Info 21-27 April 2010).

The arrival of Fadiga Moussa also coincided with a restructuring of the AMSCI's Islamic activities. In particular, the organization sought to establish a more-permanent presence in urban areas. In recent years the AMSCI has focused much effort on the Yopougon district of Abidjan, including the construction of new mosques (Fraternité Matin 10 October 2004; Islam Info 10-16 September 2008). In April 2014 the AMSCI held a joint opening ceremony for its largest mosque and headquarters in Yopougon-Wassakara neighbourhood. The building, the construction of which began in 2004, cost more than a 1000000000 CFA francs. It includes a mosque, Tawfiq Mosque, that can accommodate more than 3,000 worshippers, as well as administrative offices for the various organizations that make 
up the AMSCI. The project was entirely funded by the AMSCI and the Muhammad Habib International Foundation (Fraternité Matin 19 April 2014).

The AMSCI has been very active recently in poorer neighbourhoods of Abidjan and in certain districts of the city, in particular Yopougon, Adjamé, and Abobo. However, it has also shown clear signs of growth in the country's interior and rural areas. The AMSCI already had fifty-two chapters and sixteen regional councils spread over the entire country, the most important in Bouaké, Man, and Abidjan, but it was only after its general conference in 2007 that the organization firmly established itself in other parts of the country. During that meeting, which was chaired by Fadiga Moussa, one of the recommendations made to the association's national executive was to undertake an ambitious campaign of mobilization, development, and revitalization of local organizations across the entire country. This recommendation was framed as a call for the AMSCI to emerge from its 'lethargy', a point underscored by Abdoulaye Traoré, vice president of the J-AMSCI at the time: 'As a result of the sociopolitical crisis, we recognized that the work of associational life had been neglected. After the 2007 [general] conference, we judged it useful to tour Côte d'Ivoire to revitalize the organizations that had lost their vitality and to invest in communities where we did not have basic organizations' (Islam Info 915 June 2010).

The president himself, often accompanied by a large delegation of other representatives from the national offices of the AMSCI and the CODIS, criss-crossed the country beginning in 2008. This campaign began with a visit to Dabou in February 2008 (Islam Info, 27 February-4 March 2008). The next stops were Duékoué in April 2008 (Islam Info 23-29 April 2008); Bouaké in November 2008 (Islam Info 12-18 November 2008); Bangolo, Logoualé, Duellé, Man, Danané, and Touba in the west between 3 and 7 April 2009 (Islam Info 29 April-5 May 2009); Divo, Lakota, Gagnoa, Guibéroua, and Sinfra in June 2009 (Islam Info 15-21 July 2009); the Haut Sassandra and Worodougou regions in May 2010 (Islam Info 12-18 May 2010); and the Denguélé and Savanes regions from 8-13 May 2010 (Islam Info 9-15 June 2010). Throughout the tour leaders from the AMSCI's national office officially named new local leaders as well as leaders of regional delegations and general councils. In this way the AMSCI slowly but surely extended its presence to all parts of Côte d'Ivoire, reflecting a will to spread 'authentic' Islam to the grassroots and in villages.

In recent years the AMSCI has lost important Muslim scholars (ulama) with the deaths of Salia Bamba, president of the ANAOU, and Cheick Adama Koné, imam of the Rahma Mosque and president of the AMSCI from 1997-2007 and of the CODIS from 2007-2013. Yet it has still managed to grow its ranks with the arrival of individuals who completed their graduate studies in Arab countries. Today the CODIS is led by Imam Boun Ladj Camara, a theologian with a great deal of legitimacy and authority among the faithful. Along with Fadiga Moussa, he is one of the country's leading Salafi figures. Adam Fofana is another new figure associated with this current. Originally from Marabadiassa, a community in northern Côte d'Ivoire, Fofana left for Saudi Arabia to pursue graduate studies. He received a doctorate in Islamic studies from the Islamic University of Medinah in June 2008. His thesis on sharia is now used by the high court of justice in Medinah and can be found in Islamic libraries throughout the Arab world. During a ceremony held in his honour in Abidjan, some of the country's leading Islamic personalities underscored the extent of his knowledge (Islam Info 17-23 September 2008). Today he is the executive secretary of the ANAOU as well as a popular speaker at Sunni events. He is also the imam of the Mosquée Tawfik (Tawfik Mosque) in Riviera Palmeraie neighbourhood in Abidjan. The AMSCI also has an increasingly large number of mosques led by these new arrivals. Even if Wahhabi Muslims remain a minority in Côte d'Ivoire and are mainly present in the country's south and west, the movement is extending its sway over certain groups of Arabic speakers and over emerging Muslim contexts. 
New 'Sister' Associations: The Example of the CEEMUCI and the Growth of Salafism in Secular Schools and Among Students

In recent years Salafism has reached new groups of Arabic speakers and significant numbers of young francophone Muslims, both male and female, and especially students. Indeed, the AMSCI's preaching activities have encouraged the creation of other Salafi groups and associations in Côte d'Ivoire. Among these groups is the Communauté Estudiantine Musulmane de l'Université de Cocody et de l'École Nouvelle Supérieure (Muslim Student Community of the University of Cocody and the New School of Higher Studies, or CEMUCE), which held its founding assembly on 8 March 2003. It was renamed 'CEEMUCI' at its second general meeting on 30-31 December 2005. Today the association is present in almost all the country's schools and universities.

In some ways the CEMUCE/CEEMUCI reflects the rise of Salafism in Abidjan, especially on the campus of the University of Cocody, since the end of the 1990s. The CEMUCE was created in March 2003 after several members split from the AEEMCI. The latter had been active in the country's francophone schools and universities for forty years. Famoussa Coulibaly, the first president of the CEMUCE/CEEMUCI (2003-2008), previously served on the AEEMCI's law and economics committee at the University of Cocody. He explained the ideological reasons for his departure: 'We demanded a form of Sunni Islam that imposed strict respect for the rules of the Quran and the Sunnah. Unfortunately, the leaders of the AEEMCI at the time did not share this vision. Over time, this led to clashes between us regarding the nomination of the imams of local branches' (Al-Azan December 2005). Indeed, tensions developed on campus between Salafis and other Muslims. For example, the night-time prayer vigils organized by the AEEMCI every year on the eve of exams were denounced as bida' (Miran 2006). The Salafi student group also tried to infiltrate and eventually take control of the AEEMCI by placing members friendly to their cause on the national executive committee. However, they failed. ${ }^{29}$ Ultimately these individuals preferred the creation of a new organization that better fit their religious views. They deplored the lack of religious knowledge and submission among Muslim students involved with the AEEMCI at universities and other postsecondary institutions (Konaté 2009: 161-162). In response, the CEEMUCI secured a temporary headquarters and place of worship (Ibn Baz Mosque $)^{30}$ on the campus of the University of Cocody. ${ }^{31}$

Since 2003 CEEMUCI activists have made clothing and appearances a mark of collective identity and belonging on the campuses of the Universities of Cocody and Abobo-Adjamé. Male students wear trousers above the ankles (isbal), and maintain a full beard. Many female students wear the niqab. In the beginning, these clothing choices sparked controversy at several postsecondary institutions. ${ }^{32}$ In this context Famoussa Coulibaly clearly expressed his displeasure when the authorities criticized the students' clothing choices in December 2005: 'You know that the Quran says that a woman must be completely covered. This is the basis of the debate... If girls are allowed to wear mini-skirts, those who wish to cover themselves should be allowed to do so.... It is a matter of personal choice for the sister involved and not one of indoctrination' (Al-Azan December 2005).

Coulibaly's career provides a good illustration of how Salafism has reached new groups in Côte d'Ivoire, especially French-speaking youth educated in Western-style schools. Coulibaly was chief of staff to the Minister of Planning and Development (April 2012-January 2015). Trained in law, he completed his doctoral thesis in May 2013 at the University of Cocody, focusing on the resolution of the Liberian conflict. ${ }^{33}$ However, the CEEMUCI does not have a monopoly on young Salafi Muslims educated in French-speaking secular institutions. Indeed, Dr. Abdul Karim Dosso, president of the JEMCI since August 2008, teaches law, administration, and management at the University of Bouaké (Islam Info 17-23 September 2008). He is currently dean of the law faculty at the same institution. 
Although the CEEMUCI is not a direct offshoot of the AMSCI, the two organizations have worked very closely together. They share the same religious principles, have frequently collaborated on various events, and activists have easily moved from one association to the other. Several individuals have held positions within both organizations. For example, Bamba Abass, the CEEMUCI's head imam, has also served as secretary for the CODIS and has been very active in the AMSCI. Ousmane Diomandé was initially one of the CEEMUCI's four imams at the Ibn Baz Mosque. In his youth he studied at the Dar al quran wal hadith (House of the Quran and the Hadith) Franco-Arabic school in Man, and earned a baccalaureate (secondary-school diploma) from the Dar Al Hadith Arabic school in Bouaké. Diomandé then moved to the secular public school system, where he earned a baccalaureate in 1999. He later enrolled at the University of Cocody where he received a master's degree in economics, specializing in public-sector economics, in 2004. His Arabic was strong enough to impress the Saudi Arabian chargé d'affaires, who congratulated him on the quality of one of his Friday sermons (Islam Info 15-21 August 2007). His studies in both Arabic and public systems allowed him to move from the CEEMUCI to the AMSCI, where he was named secretary general and spokesman.

In these ways the main Salafi groups in Côte d'Ivoire have sought to develop a stronger feeling of belonging among their members. They have invested in basic infrastructure by building mosques and madrasas, and have supported the adoption of distinctive clothing habits. The increased visibility of Salafism in Côte d'Ivoire in recent years can also be explained by the AMSCI's use of media.

The AMSCI and Information and Communications Technology (ICT): A Half-hearted Embrace of New Media

In recent years the leaders of the AMSCI have recognized the need to exploit religious media and the importance of using ICT to spread their message. As Fadiga Moussa noted during his visit to the savannah region in June 2010, 'communication tools have been key to the spread of Islam' (Islam Info 915 June 2010). With this in mind, the AMSCI created the Al Fourquane radio station in 2010. The station is based in Man in western Côte d'Ivoire, and is supported by contributions from Maktab Ta' Awoun as well as Ivorian Muslims and foreign funding. The choice of Man over Abidjan can be explained by the fact that the Haute Autorité pour la Communication Audiovisuelle (High Authority for Audiovisual Communications, or HACA $)^{34}$ was concerned about the saturation of radio frequencies in the capital. In addition, Man has been traditionally perceived as fertile ground for spreading a more-rigorous version of Islam. ${ }^{35}$ The arguments made by those behind the radio station project provide a good illustration of the importance given to the media in the promotion of 'true' Islam:

Today communications are the mainstay of all ideologies. It is through the media that societies and public opinion are guided. Islam, our religion, pays the price every day. Indeed, each day the image of the religion we have inherited from our beloved Prophet Mohammed is misrepresented in the media, even those managed by Muslims, and especially in Côte d'Ivoire. Furthermore, it should be noted that the teaching of authentic Islam is less and less accessible because of the proliferation of misguided practices and ideologies. Faced with this religious decay, the AMSCI, a pioneer in the promotion of Islam in Côte d'Ivoire, has judged it necessary and essential to equip itself with a powerful communications tool adapted to the challenges faced by Muslims. ${ }^{36}$

The radio station began broadcasting in 2011, in both French and African languages. However, it has faced its share of difficulties. According to the station manager Oustaz Hassane Touré, some supervisors and employees were not sufficiently prepared and did not have the necessary training to operate a radio station. Nevertheless, those in charge have been able to rely on the support of the 'Taiba' radio network in Khartoum as they develop their own expertise. ${ }^{37}$ In the years to come the AMSCI's radio station will also likely face increased competition. Indeed, the very-popular Al Bayane 
radio station, which is broadcast throughout almost all of Côte d'Ivoire and is managed by the CNI/COSIM, installed a relay antenna in Man on 14 February 2015. The Al Bayane's managers are currently raising the funds necessary to establish a separate local station in Man (L'Intelligent d'Abidjan 18 February 2015).

In addition to the launch of the $\mathrm{Al}$ Fourquane radio station, there have been other signs that the AMSCI is placing more importance on ICT. Several training sessions have been organized to provide educational opportunities for the association's imams and preachers. For example, on 8 November 2008 at the Rama Mosque in Adjamé, about 200 imams affiliated with the CODIS attended a workshop. One of the workshop's three themes was 'Islam and ICT'. According to the president of the AMSCI, the leaders of the association had recognized that many Sunni imams 'do not yet know how to use ICT'. As a result, it was 'necessary to organize this workshop to provide them with the basic knowledge necessary to popularize the Sunnah' (Notre Voie 17 November 2008). Diallo Badani Ali, an educator with the CODIS, has noted the pressing challenge of ensuring that imams embrace the age of ICT (Notre Voie 17 November 2008). From his perspective, imams 'must know how to use computer devices to undertake research' (Islam Info 19-25 November 2008).

In the same vein, the AMSCI recently set up an official website that later went offline (www.amsci.ci). The association also launched a Facebook page in January 2014 (www.facebook.com/amsci440012886101334), although it is not updated very often. The AMSCI's words have therefore not always been followed up with actions when it comes to the media and new technologies. Rather, a small number of faithful Muslims who are not formally affiliated with the leaders of Ivorian Salafism have been primarily responsible for ensuring the visibility of the movement on the Internet. In particular, although it is not exclusively devoted to Salafi associations, the Salam.ci website (www.salam.ci) includes a large number of videos featuring Salafi preachers and imams, including Boukary Diarrassouba, Dr. Vakoualé Fofana, and Dr. Adam Fofana (Madore 2016b). In parallel with this increased visibility and in contrast to the Sunni withdrawal from debates on ivoirité in the 1990s, the AMSCI became more involved in sociopolitical issues during the crisis of the following decade.

\section{The AMSCI's Discourse AND CitIZEN PARTICIPATION SINCE THE TwENTY-FIRST CENTURY: TOWARD a LEgalist aNd MOdERATE VERSION OF SALAFI ISLAM}

During the political and military crisis that struck Côte d'Ivoire during the first decade of the twentyfirst century the AMSCI remained in the shadow of the CNI and the COSIM to some extent. Nevertheless, the Salafi association succeeded in positioning itself as a leading national religious organization by openly working for peace. The numerous abuses suffered by Muslims did not lead to a radicalization of its discourse. In recent years the AMSCI and its 'sister' associations have also sought greater involvement in their country's socioeconomic development as well as an active role in the process of reconciliation that followed a decade of crisis. All of this was done with an eye to challenging the CNI and the COSIM. The AMSCI and other main Salafi organizations and its leaders also became active in the fight against Islamic radicalism in a context where the terrorist threat to Côte d'Ivoire had never seemed so present.

\section{The AMSCI and Political Troubles in Côte d'Ivoire: Stepping Out of the Shadow Cast by the CNI and the COSIM}

The first decade of the twenty-first century was a terrible one for Côte d'Ivoire, characterized by repeated outbreaks of violence and political-religious extremism (Miran-Guyon 2015). In the 2000s Sunni leaders finally broke their silence over the poor treatment of Muslims. In general, they were content to call for peace and condemn the abuses that Muslims faced. This is exactly what these leaders did at their second general conference in June 2002, during which they addressed authorities on the topics of religious freedom and police mistreatment of the Sunni community. At the time the leaders 
of the association called for measures to be taken to put an end to this 'harassment' (Le Jour 3 June 2002).

Following the failed putsch attempt of 19 September 2002, Côte d'Ivoire was divided into a southern region under the authority of President Laurent Gbagbo's regime, and a northern one controlled by the insurgents. The Gbagbo regime and progovernment media portrayed these events as Côte d'Ivoire's September 11. The rebellion in the north of the country was equated with religious terrorism and the civil war with a battle between fanatical Muslim northerners and loyal Christian southerners. In this difficult context, between September 2002 and March 2007, Islam became less dynamic in Abidjan and the other cities of the country's south. Muslims became almost invisible as numerous Islamic associations temporarily suspended their activities in the face of the deteriorating situation. ${ }^{38}$

The Islamic scene remained dominated by Idriss Koné Koudouss of the CNI and Aboubacar Fofana of the CosIM. The latter was the influential imam of the Aghien Mosque in the Deux Plateaux neighbourhood in Abidjan, who had returned from a three-year exile in October 2006. ${ }^{39}$ Furthermore, the AMSCI was not invited to participate in the Forum of Religious Denominations at which the country's Muslims were represented by the leaders of the CNI, the COSIM, and Al Coran. Nevertheless, the AMSCI sought to play a role by organizing various activities and launching repeated appeals for peace and moderation. The association actively participated in the reconciliation process and organized numerous related events. For example, on 4 September 2005, the AMSCI held a conference on the theme of 'Lasting peace in Côte d'Ivoire: What are the Muslim community's contributions to a unified society?' Following the discussions, the event's official press release underscored how important it was for all citizens of Côte d'Ivoire to resolutely commit themselves to the path of reconciliation and peace, giving priority to national interests, and setting aside tribal, religious, or partisan considerations ( $L e$ Patriote 7 September 2005). In fact, this vision was expressed throughout the entire crisis, as reflected in the choice of theme for AMSCI's third general conference held in August 2007: 'The AMSCI: A vision of peace for a reconciled and peaceful nation'.

The youth committee of the AMSCI was also actively engaged in the peace process. In a press release published by the Islam Info newspaper in December 2008 the president of the J-AMSCI, Abdoul Karim Dosso, invited all Muslim youth to participate en masse in the census and voter registration process launched by the government following the crisis and in anticipation of the general election. Dosso also called on all young Muslims to do their civic duty by participating in this process in order to contribute to the unity and development of the nation, and to highlight their collective influence (Islam Info 24-30 December 2008). In the same vein, the J-AMSCI's first national convention was held at the end of May 2009. The theme was: 'Youth counselling: The key approach to building and consolidating peace in Côte d'Ivoire'.

The AMSCI's involvement continued right up to the presidential election in fall 2010. In this regard, the association introduced a motion at its general meeting held in September 2010, asking Laurent Gbagbo to bring all his weight to bear to ensure free elections that would mark a definitive return to peace and stability in Côte d'Ivoire. Sunni leaders also invited political parties to focus on consultation, dialogue, and moderation to help ensure a conclusive and peaceful end to the crisis (L'Intelligent d'Abidjan 2 October 2010). The AMSCI made another declaration on 13 October 2010, in which it called on citizens to remain calm: "The AMSCI expresses the hope that the election campaign will be peaceful and civilized, an election campaign focused on the force of arguments and free of all forms of violence or pressure'. At the same time, the association urged 'Sunni imams to remain neutral during the election campaign and not to transform their mosques into venues for campaign meetings'. Furthermore, the association asked the fourteen presidential candidates to 'accept the verdict at the polls and avoid sending Côte d'Ivoire into a spiral of violence'. Sunnis also called on the 'national and international 
media to ensure they treat information in a professional manner, requested that regulatory authorities ensure equitable access to public broadcasters, and encouraged and supported the Commission Électorale Indépendante (Independent Electoral Commission, or CEI) in its mission' (Notre Voie 20 November 2010).

Although Muslims were subject to widespread arbitrary violence when the postelection crisis struck at the end of November $2010,{ }^{40}$ Salafi associations avoided being caught up in a downward spiral. In a letter published in the press, the AMSCI and the CODIS addressed the burning of mosques, the assassination of imams, and the displacement of communities: 'The AMSCI and the CODIS called on the authors and sponsors of these acts of provocation to immediately withdraw from their theatre of operations all places of worship, in order to prevent this crisis that is political in nature from being carried over into the religious sphere, and to avoid having our country descend into ethno-religious conflict' (Le Patriote 21 March 2011). A few months earlier in a letter published on 23 December 2010, the AMSCI and the CODIS publicly addressed attacks against mosques (Islam Info 29 December 2010-4 January 2011).

During the postelection crisis of 2010-2011, the AMSCI and the CODIS participated in the reconciliation process alongside other Ivorian imams and associations in the same way that they had done during the previous decade. In particular, they organized an educational seminar for imams and religious leaders in May 2011 during which almost 200 people gathered at the Rahma Mosque in Adjamé district to discuss the theme of 'Entering Fully into Peace' (Le Patriote 14 May 2011). Another seminar on the same topic was organized in May 2012 (Notre Voie 8 February 2012). Reconciliation was also the central theme of the sermon given by Fadiga Moussa for Tabaski (Eid al-Adha) in 2013 (Fraternité Matin 15 November 2013). More recently, the central theme of the AMSCI's fourth general conference, held in April 2014, was 'How should the AMSCI respond to the challenges of tolerance, reconciliation, and the reconstruction of Côte d'Ivoire?' At the same event, Fadiga Moussa was returned to the office of the presidency.

The creation of the Commission Dialogue Vérité et Réconciliation (Truth and Reconciliation Commission, or CDVR) in May 2011 by President Alassane Ouattara was another opportunity for the AMSCI to try to distinguish itself from the COSIM and affirm its leadership. The CDVR was chaired by Charles Konan Banny, assisted by Mgr Paul Siméon Ahouana and Aboubacar Fofana. Beginning in July 2011 Sunni leaders let the authorities know that they did not feel represented by the COSIM and that they intended to participate in the CDVR independently (Miran-Guyon 2015: 294). Following the example of their leaders at the AMSCI's national office, local branches of the AMSCI, the J-AMSCI, and the CFAMSCI also sought to become involved in the process (Fraternité Matin 29 June 2011, 3 August 2011).

At no time did the main Salafi associations call for the state's overthrow, nor did they seek violent change or publicly call for the replacement of French-derived laws by shari'a. Most of their interventions in the public sphere were calls for peace. Hardly interested in gaining political power, Salafi groups stayed somewhat neutral, though they have increasingly cultivated moral and social activism. Another sign that the discourse of Salafi elites shifted from the spiritual domain to the social arena since the turn of the twenty-first century was the more-active participation of Sunnis in the socioeconomic development of Côte d'Ivoire.

Participation in Côte d'Ivoire's Development and Reconstruction: Salafi Islam beyond the Spiritual Arena

The mandate given to the $\mathrm{Al}$ Fourquane radio station provides a good illustration of the AMSCI's desire to move beyond the theological arena. The station mainly focuses on Salafi Islam, but it is also expected to explore Islamic citizenship. Although it primarily broadcasts religious programs intended to spread 
'true Islam', Al Fourquane is also mandated to promote human rights, as well as the human and material development of the communities it reaches. For example, 'Objectif développement' is a program that serves as a forum for discussions between development officers or agencies and the general population. Another program, 'Aw Ni Barra', ${ }^{41}$ promotes entrepreneurship. ${ }^{42}$

Young Sunnis have increasingly been demanding and playing a role in the country's economic development. For example, between 30 March and 1 April 2012, almost 100 J-AMSCI members attended a training session on entrepreneurship that covered topics including brainstorming, project development and management, and drafting business plans. The president of the AMSCI, Fadiga Moussa, stated how proud he was of this initiative taken by the movement's youth: 'By giving you the intellectual means to achieve socioprofessional integration [into society], you have opened the way to a resolution of the difficult problem of employment in our country'. As for the national president of the J-AMSCI Abdul Karim Dosso, he maintained that through this training young Sunnis were signalling their support for President Alassane Ouattara's program for youth integration (Fraternité Matin 2 April 2012). In the same vein, a national Islamic seminar organized by the JEMCI and titled 'Al Falah 2014' was held from 25 to 31 August 2014 in Man. Its central theme was 'An emerging Côte d'Ivoire looks forward to 2020: $:^{43}$ What will be the contribution of Muslim youth?' Lacina Ouattara, chargé de mission to the president of the republic and sponsor of the event, gave the address. The proceedings clearly reflected the AMSCI's growing importance within Côte d'Ivoire's public sphere. In the eyes of the country's political authorities:

by gathering more than 1,500 individuals in one place to talk about and discuss nothing but God, peace, reconciliation, and emergence, the JEMCI is sending a strong signal to both the public decision-makers and the society of Côte d'Ivoire. At the same time, the association has shown its desire and will to join the Head of State His Excellency Alassane Ouattara, who has not stopped working to unite the social fabric so long damaged and to allow the population to live decently in an emergent Côte d'Ivoire as we look forward to 2020 (Abidjan.net 1 September 2014).

Numerous other activities organized by the CEEMUCI's youth activists followed in this vein. For example, at its first general conference held in August 2008 the association decided to explore the socioprofessional integration of young Ivorians. The theme of the meeting was 'The CEEMUCI, platform for the Muslim elite of the future: Developing a policy for social cohesion and socioprofessional integration'. The central theme of the CEEMUCI's second National Educational Seminar for Elite Women, held in September 2014, was 'The problem of socio-professional integration in Côte d'Ivoire: What are the prospects for Muslim women?' As part of the event the CEEMUCI organized workshops, presentations, forums, and roundtables on how to create and manage a business, how to promote your know-how on the job market, and how to efficiently balance household responsibilities and work' (Islam Info 24-30 September 2014). The women of the CFEMSCI also pursued their own activities. In 2015 they launched a project called 'One million benefactors for the CFEMSCI'. According to Awa Ève Koné, who is responsible for financial matters in the association, the project aims to 'help Muslim women build a network of solidarity that will make them more autonomous'. This initiative also involves obtaining financing for the construction of a 'mother-child' hospital in Abidjan at an estimated cost of almost 730 million CFA francs (Islam Info 410 March 2015).

Alongside its economic activities, the AMSCI has also become more active in the field of education. It has sought to lead the push to have Islamic schools integrated into the national education system, while at the same time challenging the leadership of the CNI and the COSIM with regard to the domain of Islamic schooling. In addition to the construction of Al Fourqane University, the AMSCI and Fadiga 
Moussa organized the founding conference of the Ligue des Établissements Confessionnels Islamiques de Côte d'Ivoire (League of Islamic Religious Institutions of Côte d'Ivoire, or LECI ${ }^{44}$ ) in mid-April 2012. At the time of its launch the organization represented almost 300 Islamic establishments. The primary objectives of the LECI were the standardization of the curriculum in Islamic schools and the recognition of their diplomas (Islam Info 25 April-1 May 2012). It sought to be a formal representative of Muslim schools, capable of speaking on their behalf in discussions with the government. The creation of this organization affiliated with the AMSCI was a clear challenge to the COSIM and the CNI. The former was very close to the Organisation des Établissements d'Enseignement Confessionnel Islamique (Organization of Islamic Denominational Teaching Establishments, or OEECI), created on 6 December 1997. Aboubakar Sidiki Konaté, who was responsible for matters related to education within the COSIM, has also served as president of the OEECI since 1997. For its part, the CNI established the Écoles Confessionnelles Islamiques IQRA (ECI-IQRA) or IQRA school group ${ }^{45}$ with the support of the Islamic Development Bank in September 2003 (Binaté to be published). Alongside activities related to socioeconomic development and education, the civic engagement of the Salafi movement in Côte d'Ivoire has also been expressed through efforts to prevent the radicalization of Islam and terrorism.

The Terrorist Threat in Côte d'Ivoire: The Main Salafi Associations and the Radicalization of Islam

Since summer 2015 there has been growing concern among citizens of Côte d'Ivoire regarding the potential threat of terrorist attacks in the country. On 30 June the jihadist Salafi group Ansar Dine claimed responsibility for an attack committed in southern Mali. It was the second time in less than three weeks that an attack had occurred within twenty kilometres of the border with Côte d'Ivoire. Furthermore, Ismail Khalil, an Ansar Dine preacher, stated that his organization would increase attacks in Côte d'Ivoire, Mali, and Mauritania, countries that work with the enemies of Islam'. As a result, military reinforcements were sent to the north of the country along with forces from the United Nations mission in Côte d'Ivoire. On 3 July the National Assembly adopted an antiterrorist law designed to counter jihadist groups and bolster the country's security apparatus. All this meant that the terrorist threat was a hot topic in the country and often made the front page of local daily newspapers. 'Terrorist threat against Côte d'Ivoire: A suspected imam expelled from Ouangolo' ran as the headline in Soir Info on 7 July 2015; 'Terrorism. Jihadist threat: An imam and preacher from Mali expelled from the country' read the same day's edition of Ivoire-Presse; and an article titled 'Tracking terrorists: Imams on the run in Abidjan' appeared on the front page of Soir Info on 21 July.

The main Ivoirian Salafi organizations and leaders have been quick to condemn the radicalization of Islam. They have also sought to help prevent such incidents from reoccurring. At the beginning of September 2015, the AMSCI, the CODIS, and the ANAOU organized an assembly at Al Fourqane University on the theme of 'Islam, religion of peace and cohesion'. It was intended to raise awareness among some 200 imams and leaders of Muslim associations from different parts of the country, and improve their ability to spread the values of peace and cohesion through a series of presentations: 'Islam, jihad, and terrorism', 'Community responsibility in the face of violence and terrorism', and 'Terrorism legislation in Côte d'Ivoire'. The meeting's closing declaration continued in the same vein:

The consultative assembly reaffirms that there is a clear line separating Islam from terrorism. We strongly condemn all forms of violence, terrorism, and religious intolerance because the preservation of life is sacred in Islam.... We remain committed to peace and tolerance through a frank and always open collaboration with public authorities, following a long tradition established since the creation of the AMSCI in 1976 [the AMOCI at the time]. We invite participants to perpetuate this tradition of tolerance and respect for the laws of the republic, despite the abuses to which our members have occasionally been subject in the socioreligious history of our country. Indeed, it is the duty of every Muslim to personify 
tolerance, respect for life, and respect for rights as reflected in the Prophet Muhammad (Soir Info 8 September 2015; Islam Info 9-15 September 2015b).

Sunni leaders welcomed the adoption of preventative security measures and the responsibility shown by the government in its management of security and terrorist threats against Côte d'Ivoire. However, they also called on authorities to 'adopt a participatory approach based on consultations with the major associations in all initiatives related to the representation or consolidation of national unity and to abandon unilateral or bilateral approaches to the management of questions of general interest, thereby excluding a large majority of the members of the Muslim community' (Soir Info 8 September 2015). This was a reminder to the government of the AMSCI's desire to become more involved as a key representative of the Muslim community in its relationship with political authorities.

For its part, the CEEMUCI also sought to involve itself in the fight against terrorism. At the end of August 2015 the association organized a six-day educational seminar for Muslim youth. The event was organized around the theme 'What should be the attitude of young Muslims to the rise of extremism?' For association president Mouhamed Diané,

It was good that the youth organizations we represent could not remain indifferent to the growing awareness campaign launched by the authorities as well as by other organizations before us. It was good that we could follow suit and raise awareness among Muslim youth and more particularly the students of the dangers of all forms of extremism in order to protect ourselves against the negative consequences. Coming out of this seminar, we are launching a solemn call to youth and call on young people to educate themselves because ignorance is the mother of all evils. We must work more closely with scholars, we must listen to the grand imams of the community, and we must firmly engage with this religion, especially in its conception of the middle ground. Islam is not laxity, it is not withdrawal, but Islam is not extremism either (Islam Info 9-15 September 2015a).

Despite these various efforts toward countering violent extremism, terrorist attacks were carried out in Grand-Bassam in March 2016. The investigation is still ongoing, but so far ${ }^{46}$ investigators have found that this was the work of groups from outside the country-AQIM and Al Mourabitoun, respectively based in Algeria and Mali. On 27 March 2016, two Malians who 'actively participated' in the attack were arrested in northern Mali. In mid-April Ivorian Interior Minister Hamed Bakayoko reported that people with ties to the attack were being 'actively sought, particularly in Mali'. The suspected mastermind, a Malian named Kounta Dallah, is still at large. In the wake of these events the AMSCI, CODIS and JEMCI have made use of media, including Facebook, ${ }^{47}$ to quickly denounce terrorism in all its forms that tarnish the image of Islam as well as criticize the amalgam between Salafism and violence. ${ }^{48}$ In addition, a national Islamic seminar on Islam, terrorism, and youth organized by the JEMCI and titled 'Al Falah 2016' was held from 31 July to 6 August 2016 in Yamoussoukro. The overall objective of this event was to 'make young Muslims clearly understand that terrorism in the name of Islam is a heresy'. ${ }^{49}$ In this way, and despite significant growth, the main Salafi associations in Côte d'Ivoire and its leaders have both avoided and combatted radicalization; rather, they have shown a growing attachment to legalism in recent years.

\section{CONCLUSION}

After a decade of stagnation in the 1980s, the AMOCI's leaders, supported by a new intellectual elite, sought a fresh beginning at the start of the 1990s with the transition to the AMSCI. This desire was reflected in the importance they placed on establishing new organizational structures to better reach the faithful. Over the course of the decade, Salafism in Côte d'Ivoire moved from expressing exclusivist and intransigent views on other Islamic traditions to espousing more-moderate positions. The leaders 
of the movement made overtures to the larger Muslim community, including participating in the creation of the CNI. Preoccupied by the renaissance of their movement, Salafi elites distanced themselves from political debates on national identity in the 1990s.

At the turn of the twenty-first century continuing efforts to revitalize Salafi Islam involved the increased participation of youth and women, organized in different committees or associations affiliated with the AMSCI. After establishing closer links with the rest of the community, Sunni leaders tried to reposition the movement on the religious landscape of Côte d'Ivoire. From this perspective, they sought to affirm their leadership by distancing themselves from both the CNI and the COSIM, and by creating their own specialized organizations such as the CODIS. The arrival of Fadiga Moussa at the head of the AMSCI in 2007 was a defining moment. It was accompanied by the decentralization of Islamic activism, the revitalization of grassroots activism, and the building of Islamic infrastructure throughout the country. The vitality of Salafism in Côte d'Ivoire over the last ten years has been reflected in a variety of developments, such as the emergence of new Salafi figures, including students from the secular system, who have been behind the rise of the CEEMUCI, and by the increased visibility offered by a new media presence, especially through the creation of the Al Fourquane radio station.

During the troubled first decade of the twenty-first century in Côte d'Ivoire the AMSCI's activities in support of peace and reconciliation-as well as its involvement in economic, social, and educational initiatives - were directly related to the organization's will to assert itself at the expense of the CNI and the COSIM. This makes even more sense in a context in which the CNI's legitimacy has been waning due to the stagnation of its organizational structures and its conflicts with the leadership of CosIM. Furthermore, the COSIM's ability to mobilize the grass roots has been diminished as its leading imams have become somewhat gentrified. Even if the COSIM remains the main Muslim organization in Côte d'Ivoire, the AMSCI is increasingly becoming a key intermediary between Muslims and the authorities. Far from becoming radicalized and despite increasing levels of activism, the country's Salaft elites have demonstrated civic engagement and a legalist opposition to violence and terrorism, as the recent events in Grand-Bassam have shown. Even if the Salafi movement has remained a minority within Ivoirian Islam - albeit a strong and non-negligible one - the remarkable rise of the Salafis over the last twentyfive years and the impressive degree of dynamism they have shown through the actions of some associations make them important actors within the Muslim community in Côte d'Ivoire.

\section{BIBLIOGRAPHY}

\section{References}

Bassett, Thomas J. 2003. "Nord musulman et Sud chrétien": Les moules médiatiques de la crise ivoirienne'. Afrique contemporaine 206.2, 13-27.

Binaté, Issouf. Forthcoming. 'Côte d'Ivoire: La réforme de l'enseignement arabo- islamique au prisme des mutations sociopolitiques'. Autrepart.

Binaté, Issouf. 2016. 'Muslim NGOs in Côte d'Ivoire: Towards an Islamic Culture of Charity'. In Marie-Nathalie LeBlanc, and Louis Audet Gosselin (eds.), Faith and Charity: Religion and Humanitarian Assistance in West Africa. London: Pluto Press, 47-62.

Boubekeur, Amel, and Olivier Roy, eds. 2012. Whatever Happened to the Islamists?: Salafis, Heavy Metal Muslims and the Lure of Consumerist Islam. London: Hurst.

Cissé, Issa. 2009. 'Le wahhabisme au Burkina Faso: Dynamique interne d'un mouve- ment islamique réformiste'. Cahiers du CERLESHS XXIV.33, 1-33. 
Dozon, Jean-Pierre. 2000a. 'La Côte d'Ivoire au péril de l'“ivoirité”: Genèse d'un coup d'État'. Afrique contemporaine 193.1, 13-23.

Dozon, Jean-Pierre. 2000b. 'La Côte d'Ivoire entre démocratie, nationalisme et ethnonationalisme'. Politique africaine 78, 45-62.

Dozon, Jean-Pierre. 2007. 'Les déchirures ivoiriennes: Entre excès et manque de transcendance'. Social Compass 54.4, 593-602.

Dozon, Jean-Pierre. 2011. Les clefs de la crise ivoirienne. Paris: Karthala.

Dumbe, Yunus. 2011. 'The Salafi Praxis of Constructing Religious Identity in Africa: A Comparative Perspective of the Growth of the Movements in Accra and Cape Town'. Islamic Africa 2.2, 87-116.

Gary-Tounkara, Daouda. 2005. 'La communauté musulmane et la quête de l'égalité politique dans la Côte d'Ivoire de l'ivoirité (1993-2000)'. In Muriel Gomez-Perez (ed.), L'islam politique au sud du Sahara: Identités, discours et enjeux. Paris: Karthala, 601-620.

Gilsaa, Søren. 2015. 'Salafism(s) in Tanzania: Theological Roots and Political Subtext of the Ansār Sunna'. Islamic Africa 6.1-2, 30-59.

Griffel, Frank. 2015. 'What Do We Mean By “Salafi”? Connecting Muhammad 'Abduh with Egypt's Nūr Party in Islam’s Contemporary Intellectual History'. Die Welt des Islams 55.2, 186-220.

Hellweg, Joseph. 2011. Hunting the Ethical State: The Benkadi Movement of Côte d'Tvoire. Chicago, IL: University of Chicago Press.

Kane, Ousmane. 2003. Muslim Modernity in Postcolonial Nigeria: A Study of the Society for the Removal of Innovation and Reinstatement of Tradition. Leiden: Brill.

Kobo, Ousman M. 2012. Unveiling Modernity in Twentieth-Century West African Islamic Reforms. Leiden: Brill.

Kobo, Ousman M. 2015. 'Shifting Trajectories of Salafi/Ahl-Sunna Reformism in Ghana'. Islamic Africa 6.1-2, 60-81.

Konaté, Moussa. 2009. 'Les organisations islamiques en Côte d'Ivoire (1954-2006)', Ph.D. thesis, Université Ez-Zitouna.

Lauzière, Henri. 2015. The Making of Salafism: Islamic Reform in the Twentieth Century. New York: Columbia University Press.

LeBlanc, Marie Nathalie. 2000. 'From "Sya" to Islam: Social Change and Identity among Muslim Youth in Bouaké, Côte d'Ivoire'. Paideuma 46, 85-109.

LeBlanc, Marie Nathalie. 2003. 'Between Ethnicity, Religion and Citizenship: Young Muslims in Côte d'Ivoire'. In Catherine Coquery-Vidrovitch, Odile Goerg, Issiaka Mandé, and Faranirina Rajaonah (eds.), Etre étranger et migrant en Afrique au XXe siècle: Enjeux identitaires et modes d'insertion, vol. 1, Politiques migratoires et construction des identités. Paris: L'Harmattan, 233-259.

LeBlanc, Marie Nathalie. 2007. 'Imaniya and Young Muslim Women in Côte d'Ivoire'. Anthropologica 49.1, 35-50.

LeBlanc, Marie Nathalie. 2009a. 'Foi, prosélytisme et citoyenneté culturelle: Le rôle sociopolitique des jeunes arabisants en Côte d'Ivoire au tournant du XXIe siècle'. In Gilles Holder (ed.), L'islam, nouvel espace public en Afrique. Paris: Karthala, 173-196. 
LeBlanc, Marie Nathalie. 2009b. 'Nouveaux regards sur la vie des jeunes musulmanes en Côte d'Ivoire: Dynamiques de sociabilité chez les jeunes arabisantes au tournant du XXIe siècle'. In Laurent Fourchard, Odile Goerg, and Muriel Gomez-Perez (eds.), Lieux de sociabilité urbaine en Afrique. Paris: L'Harmattan, 435-459.

LeBlanc, Marie Nathalie. 2012. 'Du militant à l'entrepreneur: Les nouveaux acteurs reli- gieux de la moralisation par le bas en Côte-d'Ivoire'. Cahiers d'études africaines 206-207.2, 493-516.

LeBlanc, Marie Nathalie. 2014. 'Piety, Moral Agency, and Leadership: Dynamics Around the Feminization of Islamic Authority in Côte d'Ivoire'. Islamic Africa 5.2, 167-198.

Le Pape, Marc, and Claudine Vidal, (eds.). 2003 [2002]. Côte d'Tvoire: l'année terrible 1999-2000. Paris: Karthala.

Loimeier, Roman. 1997. Islamic Reform and Political Change in Northern Nigeria. Evanston, IL: Northwestern University Press.

Madore, Frédérick. 2016a. La construction d'une sphère publique musulmane en Afrique de l'Ouest. Québec/Paris: Presses de l'Université Laval/Hermann.

Madore, Frédérick. 2016b. 'L'islam ivoirien et burkinabé à l'ère du numérique 2.0'. Journal des anthropologues 146-147, 151-178.

Masquelier, Adeline. 1999. 'Debating Muslims, Disputed Practices: Struggles for the Realization of an Alternative Moral Order in Niger'. In John L. Comaroff and Jean Comaroff (eds.), Civil Society and the Political Imagination in Africa: Critical Perspectives. Chicago, IL: University of Chicago Press, 219-250.

McGovern, Mike. 2011. Making War in Côte d'Tvoire. Chicago, IL: University of Chicago Press.

Meijer, Roel. 2013 [2009]. Global Salafism: Islam's New Religious Movement. New York: Oxford University Press.

Miran-Guyon, Marie. 2015. Guerres mystiques en Côte d'Ivoire. Religion, patriotisme, violence (2002-2013). Paris: Karthala.

Miran-Guyon, Marie. 2016. 'Islam In and Out: Cosmopolitan Patriotism and Xenophobia among Muslims in Côte d'Ivoire'. Africa 86.3, 447-471.

Miran, Marie. 1998. 'Le wahhabisme à Abidjan: Dynamisme urbain d'un islam réformiste en Côte d'Ivoire contemporaine (1960-1990)'. Islam et sociétés au sud du Sabara 12, 5-74.

Miran, Marie. 2006. Islam, histoire et modernité en Côte d'Ivoire. Paris: Karthala.

Østebø, Terje. 2012. Localising Salafism: Religious Change Among Oromo Muslims in Bale, Ethiopia. Leiden: Brill.

Østebø, Terje. 2015. 'African Salafism: Religious Purity and the Politicization of Purity'. Islamic Africa 6.1-2, 1-29.

Saint-Lary, Maud. 2012. 'Du wahhabisme aux réformismes génériques: Renouveau islamique et brouillage des identités musulmanes à Ouagadougou'. Cabiers d'études africaines 206-207.2, 449-470.

Savadogo, Boukary Mathias. 2005. 'L'intervention des associations musulmanes dans le champ politique en Côte d'Ivoire depuis 1990'. In Muriel Gomez-Perez (ed.), L'islam politique au sud du Sahara: Identités, discours et enjeux. Paris: Karthala, 583-600. 
Sounaye, Abdoulaye. 2009. 'Izala au Niger: Une alternative de communauté religieuse'. In Laurent Fourchard, Odile Goerg, and Muriel Gomez-Perez (eds.), Lieux de socia- bilité urbaine en Afrique. Paris: L'Harmattan, 481-500.

Sounaye, Abdoulaye. 2015. 'Irwo Sunnance yan-no! 1: Youth Claiming, Contesting and Transforming Salafism’. Islamic Africa 6.1-2, 82-108.

Sources-Newspapers

Abidjan.net

"Cérémonie de clôture du séminaire national islamique "Al falah 2014" de la jeunesse musulmane en Côte d'Ivoire (jemci): Discours du parrain Ouattara Lacina, Chargé de mission du Président de la République', Abidjan.net, 1 September 2014.

Agence ivoirienne de presse

'L'AMSCI offre une mosquée aux fidèles du canton Gbo (Touba)', Agence Ivoirienne de Presse, 19 January 2015.

'Les musulmans de Côte d'Ivoire condamnent l'attaque terroriste de Grand-Bassam', Agence Ivoirienne de Presse, 15 March 2016

$\underline{\text { Al-Azan }}$

'Gros plan sur la CEMUCE', Al-Azan, no. 137, December 2005.

Fraternité Matin

'Une association des musulmans orthodoxes a été créée', Fraternité Matin, 6 September 1976.

'Docteur Moustapha Sy, de Médine à Daloa ... Sur les pas de Mohamed...', Fraternité Matin, 7 August 1991.

'Les musulmans chez Houphouët: Un acte chargé de signification', Fraternité Matin, 30-31 January 1993.

'Pose de 1ère pierre: Une mosquée sunnite à Yopougon', Fraternité Matin, 10 October 2004.

'Réconciliation nationale: Les musulmans sunnites d'Attécoubé s'engagent dans le processus', Fraternité Matin, 29 June 2011.

'Processus de réconciliation: La jeunesse musulmane se met à la disposition de la CDVR', Fraternité Matin, 3 August 2011.

'La jeunesse musulmane sunnite initiée à l'entrepreneuriat', Fraternité Matin, 2 April 2012.

'Tabaski 2013: Le président de l'AMSCI exhorte les Ivoiriens à tourner la page des querelles', Fraternité Matin, 15 November 2013.

'Réconciliation: l'AMSCI veut apporter sa contribution au processus', Fraternité Matin, 19 April 2014. $\underline{\text { Islam Info }}$

'Interview, Dr Soualiho Bamba (premier docteur en théologie en Côte d'Ivoire): "Les premières générations ont tracé les voies de notre succès"', Islam Info, no. 062, 3-9 January 2007.

'Imam Diomande Ousmane: Un parcours de combattant', Islam Info, no. 99, 15-21 August 2007.

'Dabou: Visite de l'AMSCI. Les Sunnites entament la restructuration de leur base', Islam Info, no. 122, 27 February-4 March 2008. 
‘AMSCI: Duékoué dans la mouvance de la redynamisation', Islam Info, no. 130, 23-29 April 2008.

'Yopougon/Zone Industrielle. Ouverture d'une nouvelle mosquée: une mosquée pour MICAO', Islam Info, no. 149, 10-16 September 2008.

'JAMSCI. Cérémonie de clôture de la 2ème Assemblée Générale Ordinaire: Un nouveau président a été désigné', Islam Info, no. 150, 17-23 September 2008.

'Bouaké. Installation de la délégation régionale de l'AMSCI: l'AMSCI a de nouveaux responsables à Bouaké', Islam Info, no. 158, 12-18 November 2008.

'Adjamé Bracodi. Atelier de formation des imams: le CODIS forme ses membres', Islam Info, no. 159, 19-25 November 2008.

'Communiqué de presse de la JAMSCI', Islam Info, no. 164, 24-30 December 2008.

'Tournée du BEN de l'AMSCI. Installation et redynamisation des structures de base: le Raïs s'est imprégné des réalités du grand Ouest', Islam Info, no. 182, 29 April-5 May 2009.

'Treichville. Première convention de la J-AMSCI: la J-AMSCI présente ses ambitions', Islam Info, no. 188, 10-16 June 2009.

'Tournée de l'AMSCI. La tournée d'installation et de renouvellement des structures continue: Les musulmans sunnites dans la dynamique d'organisation', Islam Info, no. 193, 15-21 July 2009.

'Interview avec Dr. Moussa Fadiga (Fondateur de l'UIFCI): "C'est un rêve pour moi de réaliser un noble projet au profit de toute la communauté musulmane", Islam Info, no. 233, 21-27 April 2010.

'Tournée de l'AMSCI dans les régions du Haut Sassandra et le Worodougou: Les régions du Haut Sassandra et le Worodougou mobilisées', Islam Info, no. 236, 12-18 May 2010.

'AMSCI. Tournée dans les régions des Savanes et du Denguélé: Une nouvelle vision pour la pratique d'un Islam authentique', Islam Info, no. 240, 9-15 June 2010.

'Après les attaques perpétrées contre les mosquées: Les sunnites réagissent', Islam Info, no. 269, 29 December 2010-4 January 2011.

'Yopougon Académie. AMSCI/LECIM: objectif, mobilisation réussit [sic]!', Islam Info, no. 338, 25 April-1 May 2012.

'1er congrès ordinaire de la J-AMSCI: la JEMCI remplace l'ex-j-AMSCI', Islam Info, no. 391, 8-14 May 2013.

'Cérémonie de clôture du congrès constitutif: la cellule féminine de l'AMSCI a une nouvelle organisation', Islam Info, no. 425, 15-21 January 2014.

'Cérémonie de clôture du SANFEF: L'emploi des femmes, au centre des préoccupations de la CEEMUCI', Islam Info, no. 461, 24-30 September 2014.

'Panel des musulmanes sunnites: La CFMCI s'engage contre les microbes et l'enlèvement d'enfants', Islam Info, no. 484, 4-10 March 2015.

'Première édition "Sabiboul Ilm": La CEEMUCI, plus responsable face à la montée de l'extrémisme', Islam Info, no. 511, 9-15 September 2015a.

'Yopougon Niangon. Assemblée consultative: L'AMSCI, le CODIS et l'ANAOU prônent un Islam de paix et de cohésion', Islam Info, no. 511, 9-15 September 2015b. 
'Attaque terroriste en Côte d'Ivoire: L'AMSCI et le CODIS condamnent et invitent à la collaboration de toutes les populations ivoiriennes', Islam Info, 16-22 March 2016.

\section{L'Intelligent d'Abidjan}

'Radio “Al-Bayane” a lancé sa station de Man', L’Intelligent d'Abidjan, 18 February 2015.

'Sortie de crise. Les musulmans sunnites à Gbagbo: "Pesez de votre poids pour des élections apaisées"', L'Intelligent d'Abidjan, 2 October 2010.

\section{La Voie/Notre Voie}

'La communauté musulmane chez Houphouët: Les six doléances des musulmans', La Voie, 28 January 1993.

'Islam, fonctionnement du Codis et NTIC: Les imams un peu plus outillés', Notre Voie, 17 November 2008 .

'Pose de la première pierre d'une mosquée sunnite', Notre Voie, 15 October 2010.

'Présidentielle du 31 octobre: Les musulmans sunnites veulent une campagne apaisée et civilisée', Notre Voie, 20 November 2010.

'El Hadj Fadiga Moussa (Chef des sunnites): “Que l'État se tienne à équidistance des réligions [sic]"”, Notre Voie, 8 February 2012.

\section{Le Jour}

'Message des imams et du CNI: "le Code électoral a divisé la nation", Le Jour, 9 August 1995.

'L'imam Sékou Sylla du CNI, aux politiciens: "Nous sommes fatigués de vos palabres", Le Jour, 21-22 October 1996.

'El hadj Aboubacar Fofana, président du Cosim: "L'islam n’interdit pas de faire la politique”, Le Jour, 16 June 1997.

'La nuit du Maoulid: Le CNI dénonce la haine tribale', Le Jour, 8 July 1998.

'El Hadj Aboubacar Fofana, imam de la mosquée d'Abidjan: "Être porteur de grand boubou ne veut pas dire qu'on est étranger"', Le Jour, 17 March 2000.

'Référendum constitutionnel du 23 juillet: "Le texte de l'avant projet divise les Ivoiriens au lieu de les rapprocher” déclare Idriss Koudouss’, Le Jour, 21 July 2000.

'Tracasseries policières, hausse des prix, laïcité ... les sunnites dénoncent les abus', Le Jour, 3 June 2002.

\section{Le Patriote}

'Les Imams Sunnites à propos de la crise ivoirienne: "Privilégions l'intérêt national", Le Patriote, 7 September 2005.

'Incendie des mosquées, assassinats d'Imams, déplacement des populations', Le Patriote, 21 March 2011.

'Réconciliation des Ivoiriens: Les Imams sunnites s’engagent', Le Patriote, 14 May 2011.

'Man: À l’heure de la réconciliation', Le Patriote, 24 June 2011.

$\underline{\text { Soir Info }}$ 
'Menace terroriste sur la Côte d'Ivoire: Les sunnites ivoiriens prennent position', Soir Info, 8 September 2015.

Sources_Websites

'Attaque terroriste en Côte d'Ivoire: Condamnation ferme de la jeunesse musulmane ivoirienne', JEMCI, www.jemci.net/article/attaque-terroriste-en-c $\% \mathrm{C} 3 \% \mathrm{~B} 4$ te- $\mathrm{d} \% \mathrm{E} 2 \% 80 \% 99$ ivoirecondamnation-ferme-de-la-jeunesse-musulmane-ivoirienne.

'Biographie du président', Université Al Fourqane, www.alfourqaneci.com/web/index.html.

'JEMCI en bref', JEMCI, www.jemci.net/index.php/qui-sommes-nous/jemci-en-bref.

'Mission de la Radio Al-Fourquane', Radio Al-Fourquane, www.radioalfourquane.net/index.php/alfourquane/mission-de-la-radio.

'Oustaz Hassane Touré, superviseur de la radio Alfourqane', Minarets africains, www.islam4africa.net/fr new/more.php?cat id=12\&art id=132.

'Présentation de la radio', Radio Al-Fourquane, www.radioalfourquane.net/index.php/alfourquane/presentation-de-la-radio.

'Présentation du séminaire Al Falah 2016', JEMCI, www.jemci.net/article/presentation-du-seminaireal-falah-2016.

'Qui est qui? Famoussa Coulibaly', Abidjan.net, www.abidjan.net/qui/profil.asp?id=953.

\section{NoTES}

${ }^{1}$ The former French colonial capital situated about 25 miles from Abidjan.

${ }^{2}$ On 20 November 2015, Islamist militants took 170 hostages and killed 20 of them in a mass shooting at the Radisson Blu hotel in Bamako.

${ }^{3}$ On 15 January 2016, Islamist fighters killed dozens of people in a hotel and cafe popular with foreigners in Ouagadougou.

${ }^{4}$ Practices such as Mawlid (celebration of the Prophet's birthday), pilgrimages to shrines, veneration of local figures as Muslim 'saints' and other 'pre-Islamic' practices are viewed as bida'.

5 In West African countries such as Niger (Masquelier 1999; Sounaye 2009, 2015), Nigeria (Loimeier 1997; Kane 2003), Ghana and Burkina Faso (Kobo 2012, 2015), a major characteristic of Salafi groups is its ardent opposition to Sufism, Sufi orders, and Sufi-related practices.

${ }^{6}$ The main Islamic associations have their headquarters in Abidjan. The research included semistructured interviews with leaders and activists of the main national Islamic associations of different Islamic currents. However, it proved impossible to conduct interviews with leading Salafi groups (AMSCI, CODIS, JEMCI, and CEEMUCI) because of their leaders' high level of mistrust, despite various attempts and meetings.

7 Fraternité Matin (1970-2015), La Voie/Notre Voie (1991-1996; 1999; 2002-2015), Le Patriote (19921993; 1999-2015), Le Jour(1994-2015), L'Intelligent d'Abidjan(2010-2015), Agence Ivoirienne de Presse (2011-2015), and Abidjan.net (2013-2015) were consulted.

${ }^{8}$ Largely Islam Info (2005-2015), the main Islamic newspaper in Côte d'Ivoire. It was established in 2005 under the leadership of Idriss Koné Koudouss, Conseil National Islamique's president. Islam Info is published each week by Éditions Alif and is subjected to the Loi sur la presse écrite en Côte 
d'Ivoire (Law on the Press). It covers a variety of topics such as Muslim rituals and practices, and national and international news. Its section 'Vie de la communauté' (Community News) covers Muslim community news from all Islamic currents at the local and national levels. Islam Info was particularly useful for monitoring the activities of the main Salafi groups and obtaining information about its leaders.

${ }^{9}$ Similar tensions occurred in Burkina Faso in the 1990s and 2000s. Rivalries and exacerbated tensions within Salafis in Burkina Faso resulted in violent confrontations between supporters of the two opposing factions. The Great Mosque of Zangouettin in Ouagadougou was closed by the Minister for Territorial Administration between 2002 and 2006. See Cissé (2009) and Madore (2016a).

${ }^{10}$ From the name of the adjacent bar in the disreputable area of Bracodi, where alcoholic drinks are sold.

${ }^{11}$ One of the consequences of the growth of Arab aid during the oil boom of the early 1970s was the distribution of scholarships to young people wishing to pursue studies in Arab Islamic universities. Several authors (e.g., Kobo 2015; Madore 2016a) have demonstrated how returnees from Islamic Universities in Saudi Arabia played important roles in the development of Salafism in sub-Saharan Africa and the emergence of a younger generation of Muslim scholars.

${ }^{12}$ Some authors have shown that new generations of Salafis elsewhere in West Africa gradually developed more conciliatory attitudes toward their Sufi adversaries and cultural practices previously defined as bida'. See Kobo (2015), Saint-Lary (2012), and Sounaye (2015).

${ }^{13}$ On the creation of the CNI, which was a turning point in the development of Islamic organizations in Côte d'Ivoire, see Miran (2006).

${ }^{14}$ Officially recognized in 1979, the AEEMCI represented Muslim youth educated in the secular system.

${ }^{15}$ Officially recognized in 1991, this association of Arabic-speaking Muslims represented preachers from all Islamic traditions. It also organized and coordinated activities related to da'wah.

${ }^{16}$ After Houphouët's death a brief power struggle between National Assembly President Henri Konan Bédié and Prime Minister Alassane Ouattara ensued. Bédié took power in a bloodless 'constitutional' coup d'état (Hellweg 2011), and Ouattara quickly resigned. In order to block Ouattara's candidacy in the 1995 presidential election, Bédié's camp created the concept of 'ivoirité. Ostensibly, champions of ivoirité privileged the citizenship of those Ivoirians whose ancestors had arrived in the territory now known as Côte d'Ivoire before independence. In fact, they privileged southern-descended Christians over northern-descended Muslims. New citizenship laws were passed that demanded proof that both parents had been born within the country's borders. It was difficult for northerners to prove their origins since colonial boundaries had shifted and had been permeable in the past, and many did not have documentation of their parents' birthplaces. As a result, many northerners were stripped of Ivoirian citizenship and were classified as foreigners. There were also long-standing claims that Ouattara's father had been born in Burkina Faso. The 1995 presidential election was thus boycotted by the two main opposition parties, Ouattara's Rassemblement des républicains (RDR) and Laurent Gbagbo's Front populaire ivoirien (FPI), in protest of the new electoral rules. Bédié won the election with 96 percent of the vote. According to Dozon (2000a, 2000b, 2007, 2011), ivoirite was the main factor in the social disengagement that led to the 2002 civil war. It created large numbers of 'internal foreigners', especially among Muslims in the country's north, where they had lived and worked for many years. However, there were also a large number of Muslims in the south; see Bassett (2003). For Gary-Tounkara (2005), Muslims found themselves hostage to political tensions fanned by ivoirité, while authorities played on the fear of Islam to maintain their positions of power. 
${ }^{17}$ While the CNI took care of administrative affairs for the Muslim community of Côte d'Ivoire, the COSIM saw itself as the community's moral authority. Made up of imams, the association was responsible for spiritual affairs as well as the country's mosques and imams.

${ }^{18}$ This whole debate was related to Alassane Ouattara's eligibility to run in the 2000 presidential election. It was a matter of whether or not to change the electoral code of 1995, which stipulated that candidates had to be Ivorian by birth and the child of a mother and a father who were themselves Ivorian by birth. The debate was therefore about whether to replace the 'and' with an 'or', which would have allowed Ouattara to run in the 2000 election. His opponents sought to portray Ouattara as an Ivorian of convenience since his father was from Burkina Faso, he was educated in Upper Volta, and he had represented the latter country within international organizations. For a background on how events in the 1990s and Henri Konan Bédié's role contributed to the continuing crisis in the 2000s, see Hellweg (2011), Le Pape and Vidal (2003), and McGovern (2011).

${ }_{19}$ As had been the case under Bédié, representatives of the CNI and the COSIM regularly expressed themselves on the sociopolitical situation under the military regime of Robert Guéi (1999-2000), who took power following a coup (e.g., Le Jour 16 June 1997, 17 March 2000, 21 July 2000).

${ }^{20}$ Da'wah means 'invitation', as in to read the Qur'an to discern Islam's meaning for one's life. It also means the proselytizing or preaching of Islam. Da'wab is a key concept in Salafism and Islam more generally.

21 'JEMCI en bref, JEMCI, www.jemci.net/index.php/qui-sommes-nous/jemci-en-bref.

22 The reason why the J-AMSCI had previously been headquartered in Man is unknown. However, Man as well as Bouaké, Gagnoa, and Anyama are among the first cities where the Salafi/Wahhabi movement emerged in Côte d'Ivoire. See Miran (2006).

${ }^{23}$ Abdul Karim Dosso was not the first president of the J-AMSCI. However, very little is known of the association before 2009 and hence it is impossible to determine the order of the J-AMSCI's previous presidents. Further research will need to be conducted.

${ }^{24}$ This university has been open since the 2009-2010 academic year. It was founded by the NGO of Fadiga Moussa Al Farouk, the current president of the AMSCI (2007-). University Al Fourqane is discussed in greater length in the next section of the paper.

25 'Biographie du président', Université Al Fourqane, www.alfourqaneci.com/web/index.html.

${ }^{26}$ About Dr. Fadiga Moussa Al Farouk, Imam Koudouss of the CNI, one of the leading Islamic figures in Côte d'Ivoire in the last 25 years, went so far as to say: 'He was my junior in terms of age but my elder in terms of knowledge' (Notre Voie 15 October 2010).

${ }^{27}$ Officially recognized in November 2006.

${ }^{28}$ According to the CV of Dr. Moussa Fadiga Al Farouk.

${ }^{29}$ Interview with Mohamed Cissé, AEEMCI’s president (2000-2003), Abidjan, 13 January 2015.

${ }^{30}$ CEEMUCI's members have prayed at this mosque since at least 2005. It proves impossible to verify if the Ibn Baz Mosque was their place of worship between 2003-2005. It would be interesting to investigate the meaning of the Ibn Baz Mosque's name. It is possible it is taken from the name of Abd al-Aziz ibn Baz, the former Grand Mufti of Saudi Arabia (1993-1999) and a leading proponent of Salafism. Baz was known to justify the actions of the Saudi state, giving a very different picture of the relationship between politics and Islam than the one Ivoirian Salafis have publicly pursued to date. If so, this raises the question of CEEMUCI's position vis-à-vis shari'a and the secular state, and if they eventually want to see shari'a adopted as national law in Côte d'Ivoire.

${ }^{31}$ This temporary headquarters and place of worship were destroyed during the renovation of public universities in 2011. 
${ }^{32}$ Gilsaa (2015) and Østebø (2012) show how young Salafis in Tanzania and Ethiopia advocate for the adoption of correct dress codes and outward appearances as important markers of the Salafi way of life.

33 'Qui est qui? Famoussa Coulibaly', Abidjan.net, www.abidjan.net/qui/profil.asp?id=953.

${ }^{34}$ The agency responsible for assigning radio frequencies in Côte d'Ivoire.

35 'Présentation de la radio', Radio Al-Fourquane, www.radioalfourquane.net/index.php/alfourquane/presentation-de-la-radio.

${ }^{36}$ Ibid.

37 'Oustaz Hassane Touré, superviseur de la radio Alfourqane', Minarets africains, www.islam4africa.net/fr new/more.php?cat id=12\&art id=132.

${ }^{38}$ Between 2002 and 2007 death threats, violence, and a climate of anxiety silenced many of the Muslim guides who had previously expressed themselves publicly. See Miran-Guyon (2015, 50-63, 98-107).

${ }^{39}$ These two men also developed an intense rivalry. See Miran-Guyon (2015, 155-156).

${ }^{40}$ The results of the second round of the 2010 presidential election, the first in a decade, resulted in an electoral dispute. Both of the main candidates claimed victory. Laurent Gbagbo, the incumbent president, was recognized by the Constitutional Council; Alassane Ouattara was recognized by the Independent Electoral Commission and the international community. See Miran-Guyon (2015, 214228).

${ }^{41}$ The expression 'Aw ni barra' (or 'Aw ni baara') is a Jula salutation, meaning 'Good work!' (literally 'You (plural) and work').

42 'Mission de la Radio Al-Fourquane', Radio Al-Fourquane, www.radioalfourquane.net/index.php/alfourquane/mission-de-la-radio.

${ }^{43}$ A slogan regularly used by President Ouattara ('faire de la Côte d'Ivoire un pays émergent à l'horizon $2020^{\prime}$ ). The notion of 'un pays émergent' along the lines of Ouattara's neoliberal agenda means that Côte d'Ivoire will be an emerging market and a future member of the BRIC/BRICS or BRICI groups of major emerging national economies.

${ }^{44}$ The association is also known as the Ligue des Établissements Confessionnels Islamiques et Medersas de Côte d'Ivoire (LECIM).

${ }^{45}$ The creation of a gathering of Islamic establishments integrated into the formal education system was a way for Idriss Koné Koudouss and the CNI to challenge the OEECI close to Aboubacar Fofana and the COSIM. At the beginning of 2016 ECI-IQRA had 762 students and four schools in three cities (Abidjan, Korhogo, and San-Pédro), according to numbers from the association (www.facebook.com/398164326923131/posts/1045916215481269). A fifth establishment is under construction in Bouaké.

${ }^{46}$ In June 2016.

${ }^{47}$ www.facebook.com/permalink.php?story fbid $=690843747684912 \& i d=440012886101334$.

${ }^{48}$ 'Les musulmans de Côte d'Ivoire condamnent l'attaque terroriste de Grand-Bassam', Agence Ivoirienne de Presse, 15 March 2016; 'Attaque terroriste en Côte d'Ivoire: L'AMSCI et le CODIS condamnent et invitent à la collaboration de toutes les populations ivoiriennes', Islam Info, 16-22 March 2016; 'Attaque terroriste en Côte d'Ivoire: Condamnation ferme de la jeunesse musulmane ivoirienne', JEMCI, www.jemci.net/article/attaque-terroriste-en-c $\% \mathrm{C} 3 \% \mathrm{~B} 4 \mathrm{te}-\mathrm{d} \% \mathrm{E} 2 \% 80 \% 99$ ivoirecondamnation-ferme-de-la-jeunesse-musulmaneivoirienne; www.facebook.com/Jamsci/posts/668009120006031.

49 'Présentation du séminaire Al Falah 2016', JEMCI, www.jemci.net/article/presentation-du-seminaireal-falah-2016. 